Teknomekanik

Vol. 4, No. 1, May 2021, pp. 22 29

e-ISSN: 2621-8720 p-ISSN: 2621-9980

\title{
Characteristics Particleboard Made from Areca Fiber with Tapioca and Gambier Adhesive
}

\author{
Hendri Nurdin', Waskito² and Batu Mahadi Siregar ${ }^{3}$ \\ ${ }^{12}$ Department of Mechanical Engineering, Faculty of Enginering, Universitas Negeri Padang, Padang 25131, Indonesia \\ ${ }^{3}$ Department of Mechanical Engineering, Faculty of Engineering, Universitas Negeri Medan, Medan 20221, Indonesia
}

\begin{tabular}{ll}
\hline Article Info & ABSTRACT \\
\hline Article history: & $\begin{array}{l}\text { The development of engineering materials has increased its use in various } \\
\text { fields. The engineering material is particleboard made from areca fiber }\end{array}$ \\
Received Jan $21^{\text {th }}, 2021$ & $\begin{array}{l}\text { which is processed with technology. Areca fiber as waste has the potential to } \\
\text { be used as an engineering material. The purpose of this study was to obtain } \\
\text { Revised Mar } 17^{\text {th }}, 2021\end{array}$ \\
the characteristics of the particleboard following the quality standards of JIS \\
A 5908-2003 and SNI 03-2105-2006. The process of making particleboard by \\
meywords: $26^{\text {th }}, 2021$ & $\begin{array}{l}\text { maxing particles of areca fiber and adhesive then compacting it. The } \\
\text { adhesives used are tapioca and gambier. The concentration of areca fiber } \\
\text { particles is } 90 \%, 80 \%, 70 \%, \text { and } 60 \% \text {. From this research, it was found that } \\
\text { the characteristics of the particleboard using tapioca adhesive according to } \\
\text { the quality standard and the gambier adhesive particle board did not meet } \\
\text { the standard quality. This particleboard can be used as a raw material for } \\
\text { maste }\end{array}$ \\
marticleboard \\
Quality
\end{tabular}

Corresponding Author:

Hendri Nurdin,

Jurusan Teknik Mesin, Fakultas Teknik, Universitas Negeri Padang,

Jln. Prof. Dr. Hamka Air Tawar, Padang (25131), Sumatera Barat, Indonesia

Email: hens2tm@ft.unp.ac.id

\section{INTRODUCTION}

The use of engineering materials is increasing so that it requires a more focused development into a product that is particleboard. The particleboard made of lignocellulosic material derived from plant waste and mixed with adhesive is then processed with technology so that it has the characteristic capability. According to SNI [1], particle boards are the result of a mixture of hot compressed wood particles or other lignocellulose materials with organic adhesives. Plants that have lignocellulose such as areca fiber are only wasted and have the potential to be used as engineering materials. Areca catechu is an oil palm commodity, consisting of seeds and fibers. Utilization of areca catechu is limited to extracting areca seeds which are used for medicinal ingredients, food, cosmetics, and dyes. Areca nut extraction waste, in the form of fiber which becomes waste. This condition has an impact on environmental pollution. If it burns, it has an impact on air pollution. Areca fibre waste is very likely to be processed into raw materials. The problem of abundant waste encourages engineers to take advantage of it. The existence of this engineering material encourages engineers to produce areca fibre waste into particleboard. Diversification of areca fibre waste into engineering materials in the form of particleboard with a technological process.

Innovation of particleboard engineering materials from areca fiber waste which has certain characteristics so that it becomes a product to replace wooden furniture. Through the process of improvement technology in processing this potential material, it is hoped that it will have great benefits. Innovation of engineering materials in the form of particle boards made from areca fiber waste as a substitute for wood furniture is very possible [2]. The process of making particleboard uses a compacting system with hydraulic pressure as a method of obtaining engineering materials.

Various types of research on particleboard made from plant waste have been carried out. One of the most important reasons for the increasing trend in the production of natural fiber composite is due to easy economial disposal of the wastes [3]. Research on tea leaf waste can be used as an alternative material either alone or in combination with wood particles for the manufacture of particle boards [4]. The composite board of bagasse waste has good and potential strength and deflection behavior as a substitute for wood on interior furniture [5]. The bagasse waste-based composite board obtained density characteristics of $0.41 \mathrm{gr} / \mathrm{cm}^{3}, 2.1 \%$ 
water absorption with the development of a thickness of $9.09 \%$ while drawing composite particle boards that met standard quality [6]. Development of further research on bagasse fiber-based particle composite boards using resin adhesives which yield tensile strength of $1.81 \mathrm{MPa}$, with strain $13.52 \%$ [7]. The characteristics obtained are recommendations for furniture manufacturers as the development of furniture materials in accordance with SNI standards [1]. The development of areca fibre waste-based particleboard requires continuous research at stages to obtain its characteristics. This study aims to obtain the characteristics of areca fibre waste-based particleboard by using a different adhesive as a furniture material that has quality according to standards. The application of the manufacturing method with hydraulic pressure compaction can produce particleboards of suitable quality.

\section{METHODS}

The experimental research carried out was focused on particleboard. Experimental testing related to the quality test of the resulting particleboard. The method of implementation in the manufacture of particleboard begins with collecting and drying the areca fibre waste (Figure 1.a). The areca fibre is then chopped and made into $\pm 0.6 \mathrm{~mm}$ meshing particles (Figure 1.b).

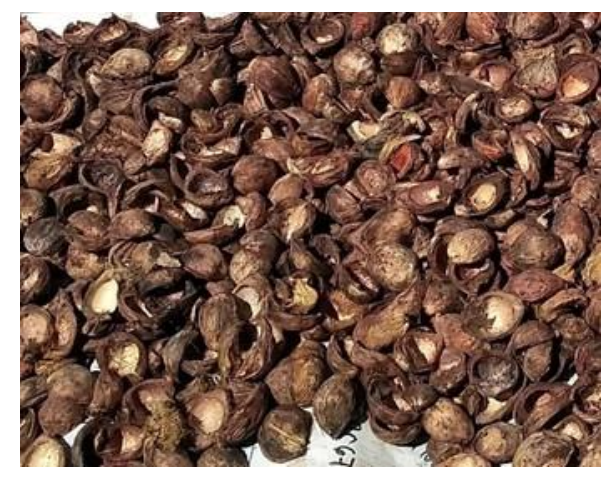

(a)

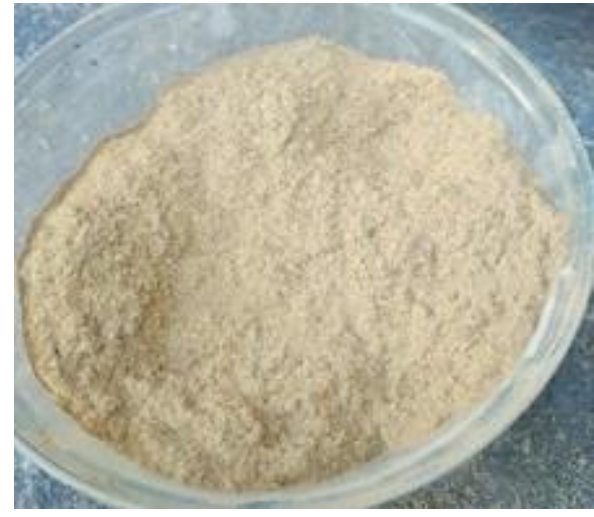

(b)

Figure 1 : (a) Areca Skin, and (b) Areca Fiber Particles

The manufacture of areca fiber particleboard using different adhesives, Tapioca (Figure 2.a) and Gambier (Figure 2.b). The use of variations in the volume fraction ratio of the areca fiber particles with a concentration of $90 \%, 80 \%, 70 \%$, and $60 \%$ [2]. The areca fiber particles and tapioca are mixed in a bowl which is then stirred and water to be added. The same process is carried out to make a particleboard using gambier adhesive. The mixture is stirred manually until evenly distributed. The next, the mixture is condition to a mould and coating with aluminium foil. The process of printing the particle board is carried out by compaction using hydraulic pressure. The particle board molding process is carried out by compaction using hydraulic pressure and followed by heat conditioning at a temperature of $120 \mathrm{C}$. The final step in obtaining this particleboard is the process of drying it through the heat of the sun in a several days. Figure 3 Type A shows a particleboard product using Tapioca adhesive and Type B shows particleboard using Gambier adhesive.

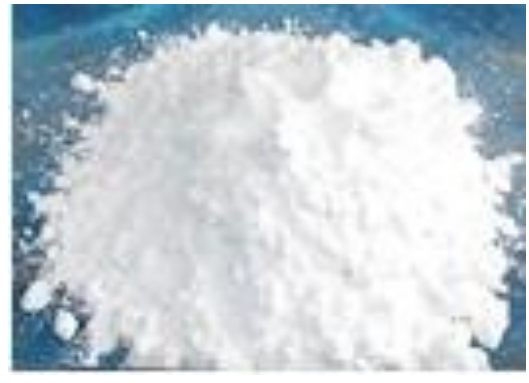

(a)

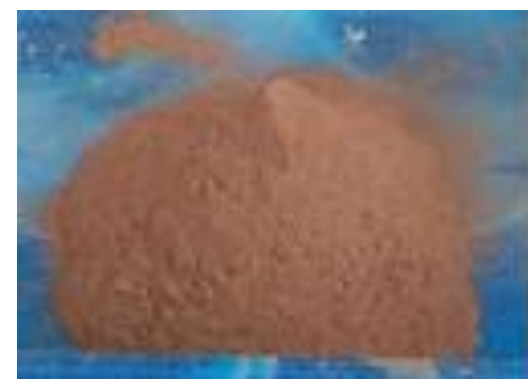

(b)

Figure 2 : (a) Tapioca, and (b) Gambier 


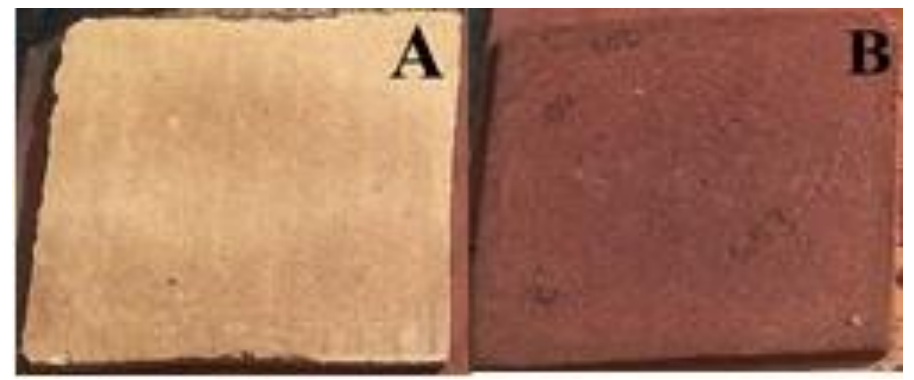

Figure 3 : Particleboard Products A and B

Furthermore, the particleboard that has been printed and dry, then cutting the test sample is carried out (Figure 4). The cutting of the test sample on the particleboard is following the standard JIS A 5908-2003 [8] and the cutting pattern is as in Figure 4. The test carried out is measuring the characteristics of the particle board using Tapioca and Gambier adhesives. Particle board products are expected to have characteristics close to the standard values of JIS A 5908-2003 [8] and SNI 03-2105-2006 [1]. The test parameters for particleboard characteristics include density, moisture content, water absorption, thickness development, modulus of rupture (MOR), modulus of elasticity (MOE), and screw holding strength. A description of the tests carried out in the form of result data through experiments and measurements. Then the analysis was carried out using calculation and tabulation of the test results. Analysis of test data processing was carried out by statistical and mathematical calculations using equations. Theoretically, the resulting calculation can be expressed as a statement of the characteristics of the test particleboard.

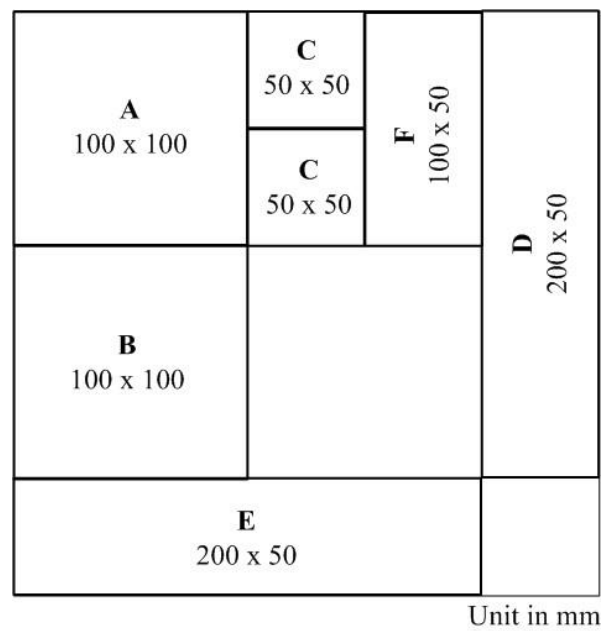

Figure 4 : Particleboard test sample cutting pattern

Caption:

A : Examples of Density tests

B : Examples of Water Absorption and Thickness Development tests

C : Example of Moisture Content test.

D : Examples of Modulus of Rupture (MOR)

E : Examples of Modulus of Elasticity (MOE)

$\mathrm{F}$ : Example of the screw holding strength test.

\section{RESULTS AND DISCUSSION}

The raw material for areca fiber particles is obtained from waste that has been disposed of. Its use in research is calculated by predicting the number of variants of the particleboard being made. From the analysis of experimental tests carried out, the characteristics of the areca fiber particleboard were obtained. The results of the density test of the areca fibre particleboard with tapioca adhesive and gambier adhesive showed different characteristics. Density is the ratio between the mass of the particleboard and its volume when dry [9]. The higher the density value the higher the strength of the particleboard. The results of the 
research on the density of particleboard made from areca fibre produce the average value as shown in the diagram (Figure 5).

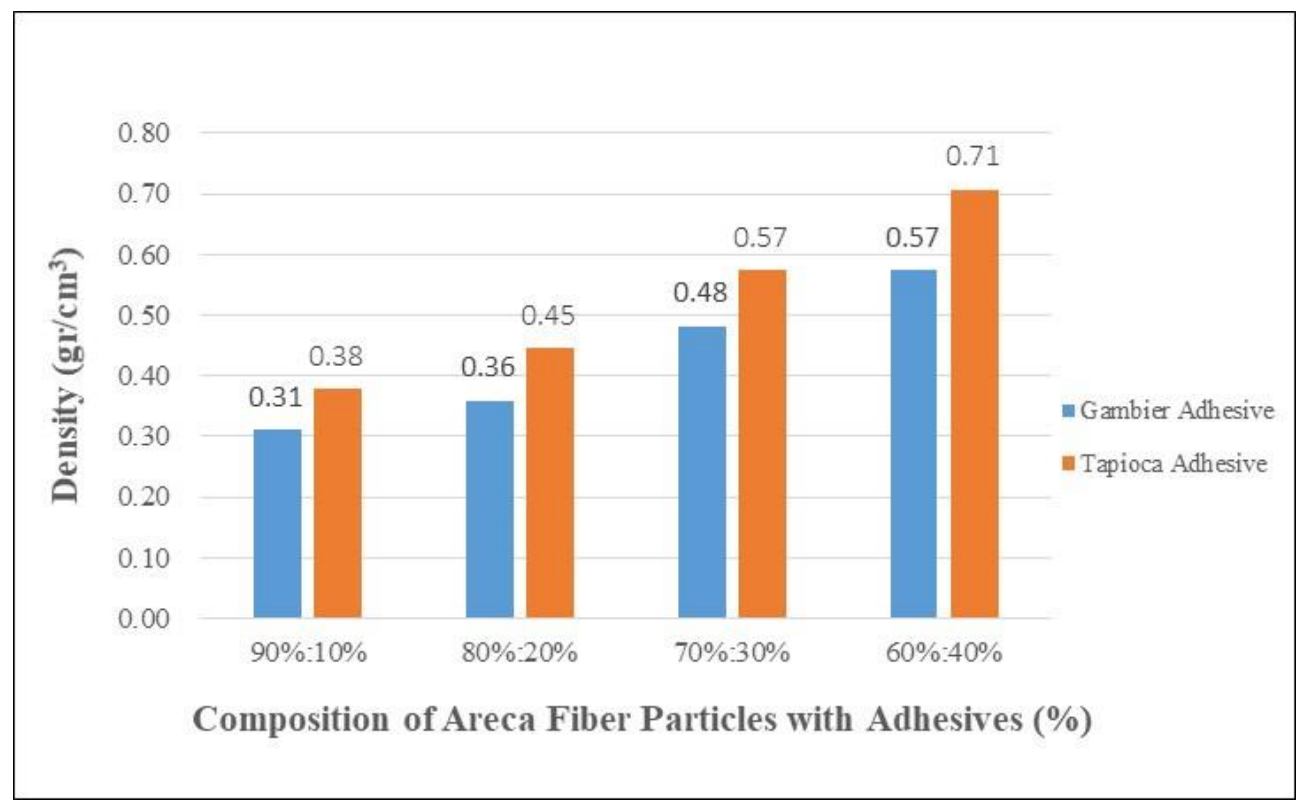

Figure 5 : Particleboard Density Diagram

The highest particleboard density was at $60 \%$ : $40 \%$ composition using tapioca adhesive with an average value of $0.71 \mathrm{gr} / \mathrm{cm}^{3}$ when compared to those using gambier adhesive with an average value of $0.57 \mathrm{gr} / \mathrm{cm}^{3}$. In other compositions, it can be said that the use of tapioca adhesive has a higher density value than using gambier adhesive. The result statement research, the more adhesives used in manufacture particleboard were the higher the strength and density of the particleboard [10]. This happens because the use of adhesives causes maximum bonding between particles and adhesives. This is reinforced by from the research statement of that the amount of material, the state of the material, and the compression technique affect the results of the particleboard density [11]. In addition, the use of the type of adhesive in the process of making composite boards greatly affects the density value of the resulting particle composite board [12].

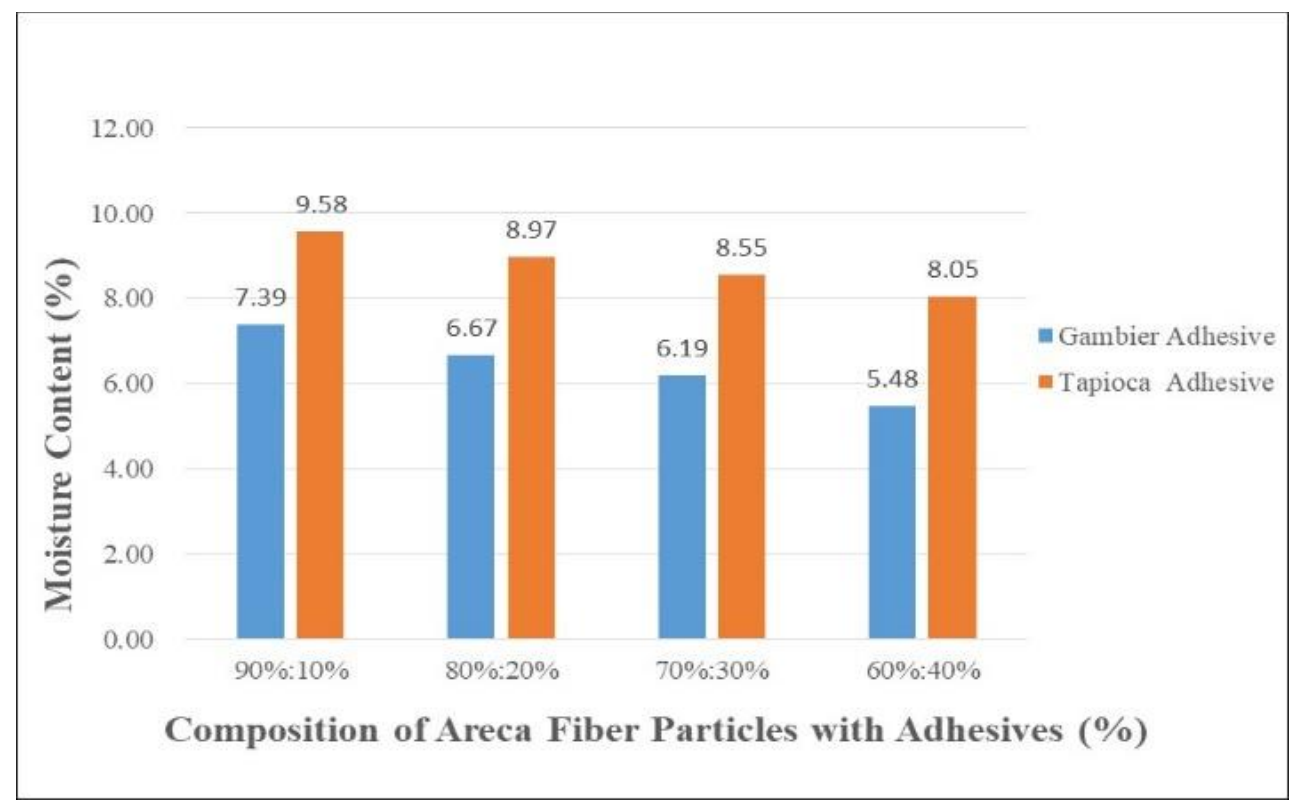

Figure 6 : Particleboard Moisture Content Diagram 
Another parameter is the moisture content value of particleboard with tapioca adhesive at a concentration of $60 \%$ areca fibre obtained $8.05 \%$. Particleboard with gambier adhesive at a concentration of $60 \%$ areca fibre obtained a moisture content of $5.48 \%$. Testing of several variants of particleboard with the use of each adhesive is shown in Figure 6. According to JIS A 5908-2003 standards, the moisture content of particleboard is 5-13\% and SNI 03-2105-2006 standard water content <14\%. This shows that the moisture content of the particleboard obtained is according to the standard. The composition and type of adhesive used have an impact on the moisture content characteristics of the particle board. The moisture of content particleboard is determined by the initial moisture content of the particles, the amount of water in the adhesive, environmental conditions and the amount of water that evaporates when dried.

The thickness development characteristic (Figure 7) of the particleboard with gambier adhesive at a concentration of $60 \%$ areca fibre was obtained $2.29 \%$. Particleboard with tapioca adhesive at a concentration of $60 \%$ areca fibre obtained $5.78 \%$. According to SNI 03-2105-2006, the development of particle board thickness is a maximum of $12 \%$, so that this characteristic is by the standard. The thickness development is related to the water content characteristic, the higher the water content characteristic, the greater the thickness development. It should be noted that thick swelling and water absorption are not limiting factors for interior particle board panels, adding a crosslinking agent can reduce these characteristics [13]. The thickness development of the particleboard is influenced by the density of forming particles. Particleboard with a low density of forming particles will experience a greater thickness development at the time of manufacture so that when immersed in water the thickness development value is higher. The large particle size of the areca fibre is easier to absorb water, thus affecting the thickness development of particleboard. Particleboard made from areca fibre with tapioca or gambier adhesives, obtained thickness development characteristics included in the standard value so that it shows very good condition.

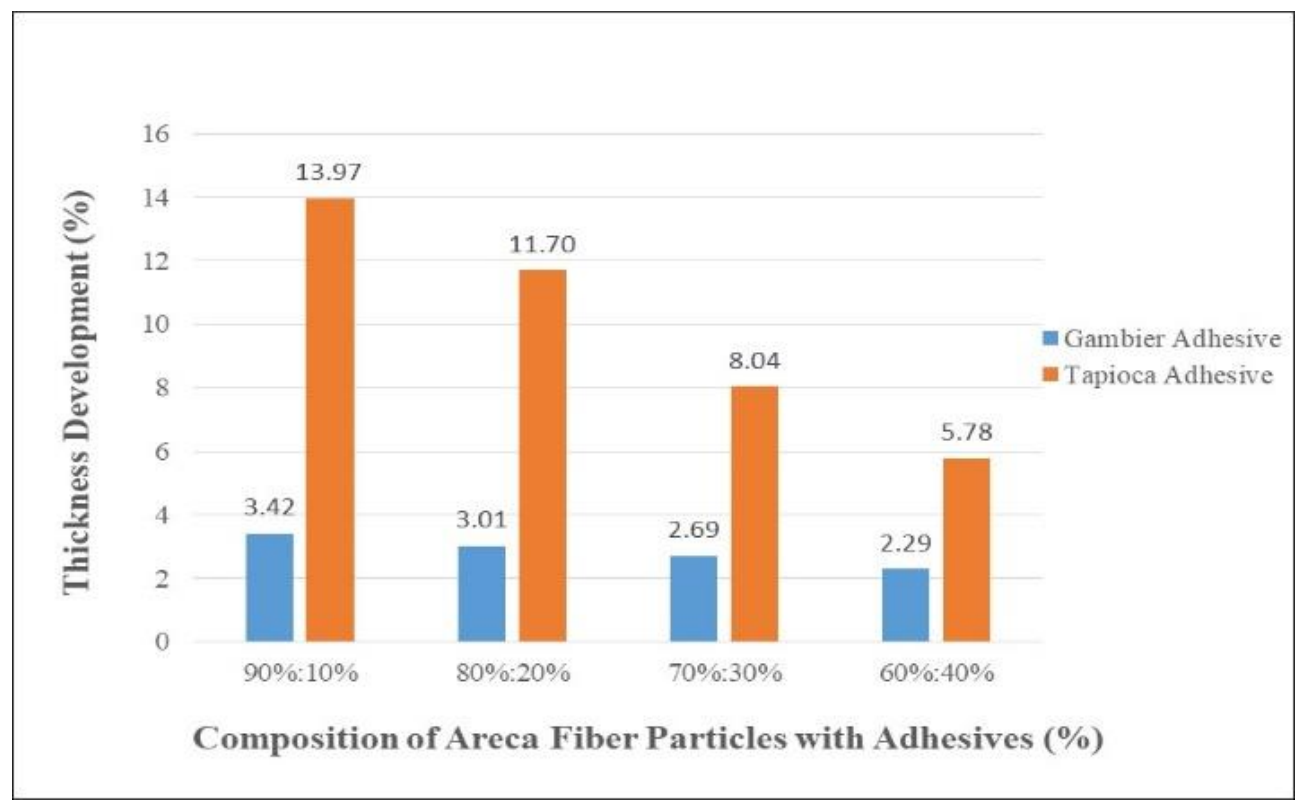

Figure 7 : Particleboard Thickness Development Diagram

The Modulus of Rupture (MOR) is an important characteristic of particleboard. Modulus of Rupture is the ability of an object to withstand the load to the maximum extent. The Modulus of Rupture in particleboards using tapioca adhesive with the concentration of $60 \%$ areca fibre obtained $73.31 \mathrm{~kg} / \mathrm{cm}^{2}$. Particleboards using gambier adhesive same with the concentration, obtained the Modulus of Rupture value lower i.e. $17.69 \mathrm{~kg} / \mathrm{cm}^{2}$. Figure 8 is shows diagram of the several test results for the modulus of rupture characteristics of particleboards. According to SNI 03-2105-2006, the Modulus of Rupture of particleboards have $82 \mathrm{~kg} / \mathrm{cm}^{2}$, this indicates that the particleboard from areca fibre produced does not standard. The concentration and type adhesives in used the manufacture of particleboard are directly proportional to the Modulus of Rupture, so the higher the adhesive content the greater the Modulus of Rupture of the particleboard [14]. 


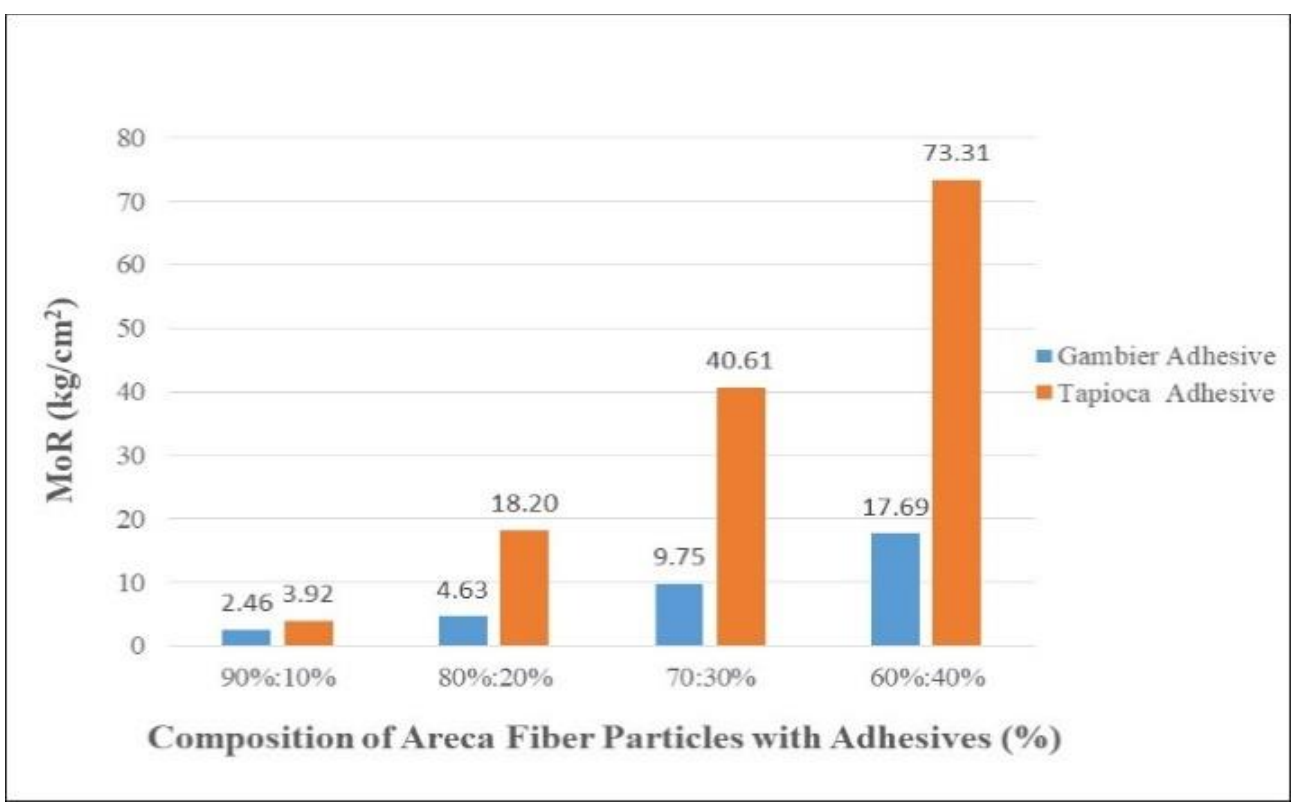

Figure 8 : Particleboard Modulus of Rupture Diagram

The Modulus of Elasticity (MoE) is the flexibility of an object in holding the maximum load before the proportional limit or before breaking. The Modulus of Elasticity in particleboards using tapioca adhesive with the concentration of $60 \%$ areca fibre obtained $4761.68 \mathrm{~kg} / \mathrm{cm}^{2}$. Particleboards using gambier adhesive same with the concentration, obtained the Modulus of Rupture value lower i.e. $3656.67 \mathrm{~kg} / \mathrm{cm}^{2}$. Figure 9 is shows diagram of the several test results for the Modulus of Elasticity characteristics of particleboards.

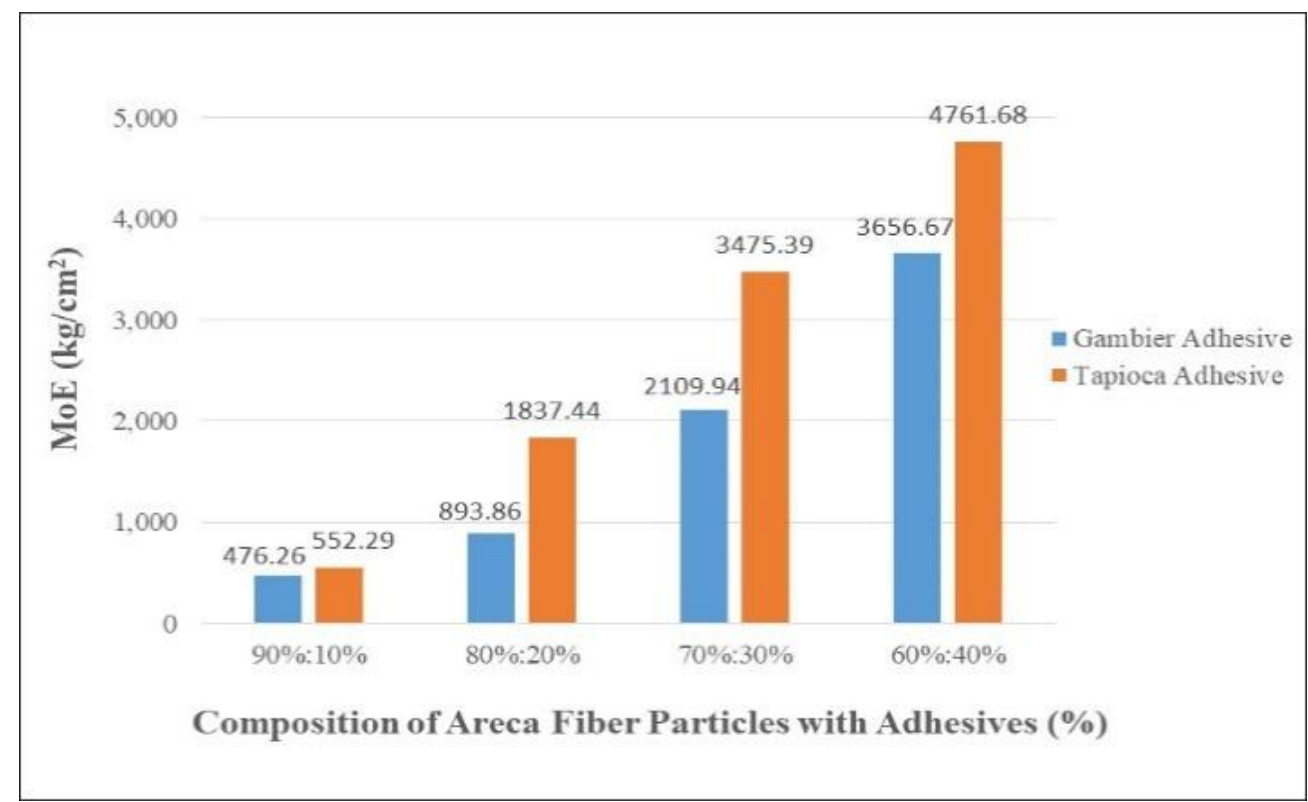

Figure 9 : Particleboard Modulus of Elasticity Diagram

According to SNI 03-2105-2006, the Modulus of Elasticity of particleboards have $20400 \mathrm{~kg} / \mathrm{cm}^{2}$, this indicates that the particleboard from areca fibre produced does not standard. In particleboard testing, the Modulus of Elasticity characteristics for the ratio variation is influenced by the use of the type of adhesive. The type of adhesive used in the manufacture of particleboard can have a very significant effect on the mechanical properties of particleboard, of course depending on the type of wood or plant [15]. Particleboard with tapioca adhesive has a greater Modulus of elasticity compared to gambier adhesive particleboard. In 
addition to the use of this type of adhesive, the concentration of the amount of adhesive affects the characteristics of the Modulus of Elasticity of the particleboard. A high concentration of adhesive can spread the adhesion wider so that internal bonding of the particles is getting stronger. Particleboard with a low concentration of adhesive internal bonding particles easily detaches which has an impact on the Modulus of Elasticity. Raw materials also determine the characteristics of particleboard, raw materials in the form of powder or particles will require a lot of adhesive compared to wood raw materials [16]. Adhesive concentration is directly proportional to the modulus of elasticity, where the value is higher as the adhesive concentration increases [14]. This condition also has an impact on improving the characteristics of particleboard such as the modulus of rupture and screw holding strength.

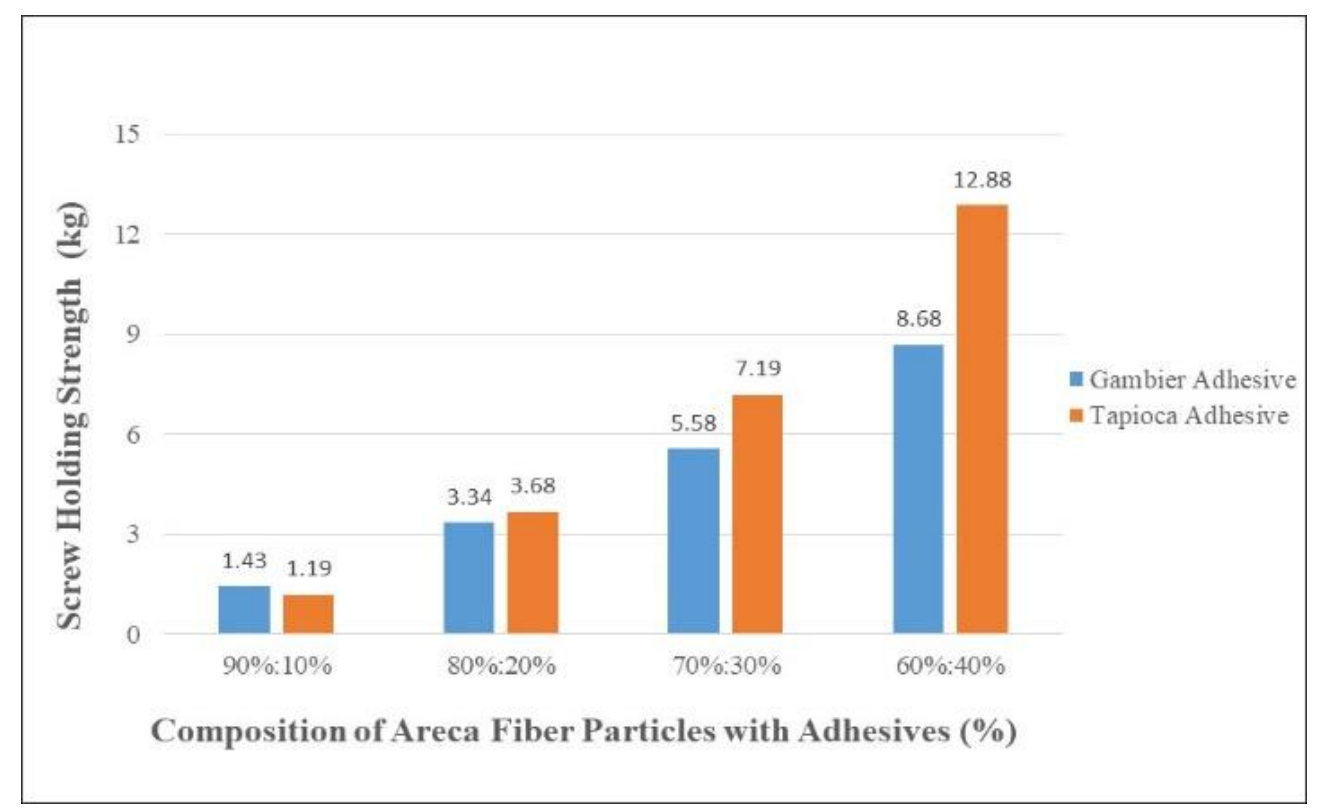

Figure 10 : Particleboard screw holding strength Diagram

The characteristics of particleboard that need to be tested in this study are screw holding strength. These characteristics indicate the ability of the particleboard to withstand the maximum screwing load of given particleboard (Figure 10). Particleboard that used tapioca adhesive with a concentration of $60 \%$ areca fiber has a screw holding strength of $12.88 \mathrm{~kg}$. Particleboard with gambier adhesive at the same concentration obtained a screw holding strength of $8.68 \mathrm{~kg}$. From these two types of particleboard, the value of the screw holding strength obtained has not reached the standard quality of $30 \mathrm{~kg}$. Figure 10 shows the test results of the two types of particle board with different adhesives. The holding strength of the screw is greatly influenced by the density value of the particleboard. Particleboard that has a high density will produce a high screw holding strength. The particleboard strength was determined by bonding strength among particles and the strength of the particles themselves [17]. Particleboard made from areca fibre is included in the type of particleboard with medium density, this is a factor why the holding strength of particleboard screws made from areca fiber does not meet the standard.

\section{CONCLUSION}

The conclusion of this study is the successful utilization of the potential of areca fiber waste into engineering materials form the particleboard. Areca fiber waste is processed by manual technology, produced as the particleboard which has characteristics. Particleboard made from areca fiber with tapioca and gambier adhesives has characteristics that meet the standards of JIS A 5908-2003 and SNI 03-2105-2006 including density, moisture of content, thickness development, and Modulus of Rupture. The characteristics of the particleboard obtained are made with a concentration of $60 \%$ areca fiber and $40 \%$ of tapioca and gambier adhesives. Particleboard with tapioca adhesive has better characteristics than particleboard with adhesive gambier. This shows the effect of using adhesive in the manufacture of particleboard on the characteristics of the product. In addition, the impact of the concentration adhesive use also affects the characteristics of particleboard 


\section{REFERENCES}

[1] B. S. Nasional, "SNI 03-2105-2006 (Revisi SNI 03-2105-1996) Mutu Papan Partikel,” BSN. Jakarta, 2006.

[2] H. Nurdin and A. Kurniawan, "Particle Board Made From Areca Fiber With Tapioca Adhesive," in Journal of Physics: Conference Series, 2020, vol. 1594, no. 1, p. 012031.

[3] P. Sudha, K. Nasreen, and P. A. Vinodhini, Natural fiber composites and applications. Apple Academic Press, Oakville, Canada, 2015.

[4] M. A. Batiancela, M. N. Acda, and R. J. Cabangon, "Particleboard from waste tea leaves and wood particles," Journal of Composite Materials, vol. 48, no. 8, pp. 911-916, 2014.

[5] H. Nurdin, H. Hasanuddin, I. Irzal, and P. Purwantono, "Analysis of Behavior Deflection Composite Particle Board Cane Baggase Using Adhesives Tapioca,” 2015.

[6] H. Nurdin, Hasanuddin, and Irzal, "Karakteristik Papan Komposit Partikel Berbahan Baku Ampas Tebu Menggunakan Perekat Tapioka Sebagai Furniture," Aptekindo, 2016. .

[7] H. Nurdin, Y. Fernanda, and M. Handayani, "Analysis of Tensile Strength the Fiber Bagasse Particles Board with Resin Adhesives," 2018.

[8] J. S. Association, Japanese Industrial Standars JIS A 5908: 2003. Particleboard, 2003.

[9] J. L. Bowyer, R. Shmulsky, and J. Haygreen, "Forest products and wood science: an introduction. 5th," 5th/Ed. John Wiley, Minneapolis, MN, 2007.

[10] H. Nurdin and M. Saddikin, "Characteristics of Particleboard From Waste Nypa Fruticans Wurmb," in Journal of Physics: Conference Series, 2019, vol. 1387, no. 1, p. 012103.

[11] P. Sutigno, "Mutu Produk Papan Partikel," 2000.

[12] H. Nurdin and N. R. Purwantono, "Pengaruh Perekat Terhadap Kerapatan Papan Komposit Berbahan Baku Ampas Tebu," Prosiding PB3I ISBN, pp. 8-13, 2014.

[13] E. Amini, M. Tajvidi, D. J. Gardner, and D. W. Bousfield, "Utilization of cellulose nanofibrils as a binder for particleboard manufacture," BioResources, vol. 12, no. 2, pp. 4093-4110, 2017.

[14] S. Ruhendi and T. Sucipto, "Pengembangan Perekat Likuid dan Papan Partikel dari Limbah Tandan Kosong Sawit,” Jurnal Ilmu Pertanian Indonesia, vol. 18, no. 2, pp. 115-124, 2014.

[15] A. Nuryawan, M. Y. Massijaya, and Y. S. Hadi, "Sifat fisis dan mekanis oriented strands board (OSB) dari akasia, ekaliptus dan gmelina berdiameter kecil: pengaruh jenis kayu dan macam aplikasi perekat," Jurnal Ilmu dan Teknologi Hasil Hutan, vol. 1, no. 2, pp. 60-66, 2008.

[16] I. Mawardi, "Mutu Papan Partikel dari Kayu Kelapa Sawit (KKS) Berbasis Perekat Polystyrene," Jurnal Teknik Mesin, vol. 11, no. 2, pp. 91-96, 2009.

[17] R. Liao, J. Xu, and K. Umemura, "Low density sugarcane bagasse particleboard bonded with citric acid and sucrose: Effect of board density and additive content," BioResources, vol. 11, no. 1, pp. 2174-2185, 2016. 